\title{
Irfani
}

ISSN 1907-0969 E ISSN 2442-8272

Volume 15 Nomor 2 Desember 2019

Halaman 53-58

http://journal.iaingorontalo.ac.id/index.php/ir

\section{PERAN GURU PENDIDIKAN AGAMA ISLAM DALAM MENGATASI KENAKALAN REMAJA DI SMKN 1 BONE RAYA KABUPATEN BONEBOLANGO}

\author{
Umar S. Usu ${ }^{1}$, Lahaji $^{2}$, Damhuri $^{3}$ \\ Pascasarjana IAIN Sultan Amai Gorontalo \\ email:umars.usu@gmail.com
}

\begin{abstract}
ABSTRAK
Tujuan dalam penelitian ini adalah yaitu: mengetahui bagaimana peranan guru pendidikan agama islam dalam mengatasi kenakalan remaja di SMKN 1. Bone raya, kabupaten bone bolango serta untuk mengetahui apa saja hambatan-hambatan guru pendidikan agama islam dalam mengatasi kenakalan remaja di SMKN 1. Bone raya. Jenis penelitian yang digunakan adalah penelitian kualitatif deskriptif yaitu penelitian yang berusaha menyuguhkan dengan sistematis dan cermat fakta-fakta aktual dan sifat populasi tertentu. Teknik pengumpulan data digunakan metode observasi, interview, wawancara dan dokumentasi. Tahap-tahap penelitian meliputi : orientasi, tahap pengumpulan data (lapangan), tahap pengumpulan data. Analisa data meliputi teknik analisis deskriptif kualitatif, sehingga hasil dari penelitian ini lebih banyak menghasilkan data-data yang tertulis atau lisan dari orang-orang dan perlilaku yang diamati. Hasil penelitian ini diperoleh sebuah kesimpulan bahwa, 1) adanya kenakalan remaja di SMKN 1. Bone Raya seperti kenakalan ringan yaitu gaduh di kelas kurang menghormati guru yang sedang mengajar, membolos, berpakaian yang tidak sesuai dengan aturan sekolah. Adapun kenakalan yang mengganggu ketentraman orang lain adalah mencuri barang teman, tauran antara sekolah. Adapun kenakalan terakhir adalah pacaran dalam kelas. 2) peran guru pendidikan agama islam di SMKN 1. Bone raya bersifat Prefentif (pencegahan) yaitu: adanya kegiatan ramadahan, mentoring, istigosah, bentuk keteladanan, dan kajian agama islam. Tindakan yang bersifat kuratif yaitu penanganan secara umum berupa: teguran dan nasihat dengan pendekatan keagamaan, memberikan perhatian khusus secara wajar kepada siswa yang bermasalah, melakukan kerja sama dengan orang tua siswa. Langkah penaganan secara khusus yaitu dengan melakukan pendekatan secara khusus per kasus secara individual. 3). Faktor-faktor penghambat peranan guru pendidikan agama islam dalam mengatasi kenakalan remaja di SMKN 1. Bone raya, yaitu: masih kurangnya kesadaran dari orang tua terhadap pendidikan anak, kurangnya pengawasan orang tua terhadap kehidupan pergaulan anak, adanya masalah broken home pada orang tua, kurangnya kesadaran dari diri siswa untuk mematuhi tata tertib sekolah, semakan banyak program televisi yang tidak mendidik.
\end{abstract}

Kata Kunci: Guru Pendidikan Agama Islam, Kenakalan remaja. 


\section{Irfani}

ISSN 1907-0969 E ISSN 2442-8272

Volume 15 Nomor 2 Desember 2019

Halaman 53-58

http://journal.iaingorontalo.ac.id/index.php/ir

\section{PENDAHULUAN}

Menurut sudut pandang yang luas, pendidikan dalah segala jenis pengalaman kehidupan yang mendorong timbulnya minat belajar untuk mengetahui dan kemudian bisa mengerjakan sesuatu hal yang telah diketahui tersebut. ${ }^{1}$ Pendidikan adalah usaha sadar yang dilakukan yang dilakukan pemerintah melalui kegiatan bimbingan, pengajaran dan latihan, yang dilakukan disekolah atau diluar sekolah, sepanjang hayat untuk mempersiapkan peserta didik agar dapat memainkan peranan, dalam berbagai lingkungan secara tepat dimasa yang akan datang. ${ }^{2}$ Baik itu lingkungan sekolah maupun masyrakat. Oleh karena itu dalam menentukan keberhasilan sebuah tujuan pendidikan lingkunagan merupakan faktor yang sangat berpengaruh, baik itu lingkungan keluarga, lingkunagan sekolah juga lingkunagan masyarakat.

Pendidkan atau guru pendidikan agama islam adalah yang melakukan kegiatan bimbingan, pengajaran atau latiahan secara sadar terhadap peserta didiknya untuk mencapai tujuan pendidkan agama islam. ${ }^{3}$ Pada prinsipnya guru wajib bertanggung jawab atas terselenggaranya pendidikan. Masalah perilaku siswa dan kebiasaan siswa yang berbeda karena latar belakang yang berbeda juga termasuk tanggung jawab guru terutama guru agama khususnya.

Kenakalan siswa merupakan masalah yang dirasakan sangatlah penting dan menarik untuk dibahas karena seseorang yang namanya siswa yang merupakan bagian dari generasi muda adalah aset nasional dan merupakan tumpuan harapan bagi masa depan Bangsa dan Negara serta Agama. Untuk mewujudkan kesemuanya demi kejayaan Bangsa dan Negara serta Agama kita ini, maka sudah barang tentu menjadi kewajiban dan tugas kita semua baik orang tua, guru dan pemerintah. Untuk mempersiapkan generasi muda menjadi generasi yang tangguh dan berwawasan/ berpengetahuan yang luas dengan jalan membimbing dan mengarahkan mereka semua sehingga menjadi warga negara yang baik dan bertanggung jawab secara moral.

Berdasarkan hasil obvervasi pendahuluan dengan mewawancarai bapak Irfan Gunibala,S.Pd.I., M.Pd selaku Guru Agama islam di SMKN 1. Bone Raya diperoleh keterangan bahwa dilakukan oleh peneliti, dimana kadang guru merasa geram dengan tingkah laku anak-anak ketika bermain di kelas. Anak jaman sekarang tidak takut pada guru dan menunjukkan wajah yang marah ketika ditegur. Ketika ada siswa yang bermasalah sebagai guru berusaha mendekatinya dengan baik dan mencari penyebab tingkah laku yang menyimpang tersebut. Kadang tingkah laku tersebut dilatar belakangi karena kurangnya perhatian di rumah dan sekolah menjadi tempat pelampiasan emosinya". ${ }^{4}$

\footnotetext{
${ }^{1}$ Suparlan, wawasan pendidikan, (Yogyakarta: Ar-Ruzz Media, 2008) h. 43

${ }^{2}$ Binti Maunah, landasan pendidikan, (Yogyakarta : Teras 2009) h. 3

${ }^{3}$ Muhaimin, paradigma pendidikan islam upaya mengefektifkan pendidikan islam di sekoalah, ( Bandung: PT remaja rosdakarya, 2012), h. 76.

${ }^{4}$ Hasil wawancara dengan bapak Irfan Gunibala S.Pd.I, M.Pd. Jum'at 21 April 2017
} 


\section{Irfani}

ISSN 1907-0969 E ISSN 2442-8272

Volume 15 Nomor 2 Desember 2019

Halaman 53-58

http://journal.iaingorontalo.ac.id/index.php/ir

Berdasarkan uraian di atas, penulis dapat memformulasikan judul penelitian yakni "Peran Guru Pendidkan Agama Islam dalam Mengatasi Kenakalan Remaja Di SMKN1. Bone Raya. Kabupaten Bonebolango".

\section{GURU PENDIDIKAN AGAMA ISLAM}

Guru juga berarti orang dewasa yang bertanggung jawab memberi pertolongan pada peserta didiknya dalam perkembangan jasmani dan rohaninya, agar mempunya tingkat kedewasaan, mampu berdiri sendiri dan memenuhi tingkat kedewasaanya, mampu berdiri dan memenuhi tugasnya sebagai hamba Allah SWT. Dan mampu melakukan tugas sebagai mahluk sosaial dan sebagai mahluk individu yang mandiri. ${ }^{5}$ Menurut UU Nomor 14 Tahun 2005 tentang guru dan dosen dimana dinyatakan bahwa kompetensi adalah seperangat pengetahuan, keterampilan, dan perilaku yang harus dimiliki dan dikuasai oleh guru dan dosen dalam melaksanakan tugas keprofesionalan. Kompetensi yang dimaksud adalah meliputi kompetensi pedagogik, kompetensi profesional, kompetensi sosial, dan kompetensi kepribadian. ${ }^{6}$

Guru merupakan santapan jiwa dengan ilmu, pembina ahlak yang mulia dan meluruskan perilaku yang buruk. Guru mempunyai kedudukan yang tinggi dalam islam. Oleh karena itu guru agama islam harus mampu menjadi tauladan yang baik bagi muridnya dalam tingkah laku sehari-hari, sehingga semua itu mampu mencerminkan ajaran agama yang telah ia sampaikan kepada para siswa. Guru agama harus bisa memadukan antara ilmu, amal dan keikhlasan.

\section{KENAKALAN REMAJA}

Kenakalan remaja bisa diartikan sebagai suatu kelalaian tingkah laku, perbuatan atau tindakan remaja yang bersifat asosial yang melanggar norma-norma dalam masyarakat. Sedang ditinjau dari segi agama, jelas sudah bahwa apa yang dilarang dan apa yang perintah oleh agama. Dan sudah barang tentu semua yang dianggap oleh umum sebagai perbuatan nakal, adalah hal-hal yang dilarang agama ${ }^{7}$. Kenakalan remaja adalah suatu penyimpangan tingkah laku yang dilakukan oleh remaja hingga menggangu ketentraman diri sendiri dan orang lain. Bila ditinjau dari segi ilmu jiwa maka kenakalan adalah sebagai manivestasi dari gangguan jiwa atau akibat dari tekanan-tekanan batin yang tidak dapat diungkapkan dengan wajah. Atau dengan kata lain bahwa kenakalan anak remaja adalah ungkapan dari ketegangan perasaan, kegelisahan dan kecemasan atau tekanan batin ${ }^{8}$.

Sudah dijelaskan dari berbagai pengertian tersebut, maka dapat disimpulkan bahwa kenakalan remaja adalah tindakan dan perbuatan yang dilakukan anak remaja dan perbuatan itu bersifat melawan hukum, anti sosial, susila dan melanggar norma agama.

\footnotetext{
${ }^{5}$ Abdul Mujib, et al. ilmu pendidikan islam, (Jakarta: Prenada Media, 2006) h. 27

${ }^{6}$ Sidik, Firman. "KONSEP PENGEMBANGAN KURIKULUM PENDIDIKAN ISLAM." (2016):

${ }^{7}$ Zakiyah Daradjat,Kesehatan Mental,Bulan Bintang, Jakarta, 1989, hal. 112

${ }^{8}$ Ibid, hal. 112-113
} $100-114$. 


\section{Irfani}

ISSN 1907-0969 E ISSN 2442-8272

Volume 15 Nomor 2 Desember 2019

Halaman 53-58

http://journal.iaingorontalo.ac.id/index.php/ir

\section{PERAN GURU PENDIDIKAN AGAMA ISLAM DALAM MENGATASI KENAKALAN REMAJA}

Guru merupakan pendidik formal di sekolah yang bertugas memberi pengajaran peserta didiknya sehingga memperoleh barbagai pengetahuan, keterampilan, nilai dan sikap yang semakin sempurnah kedewasaan dan kepribadiannya. Tugas guru agama adalah menyempurnahkan, membersikan, membawa hati manusia untuk lebih mendekatkan diri kepada sang pengcipta. Jika seorang guru agama belum mampu membawa siswanya mencapai kebiasaan dalam melakukan ibadah, meski prestasi akademis dapat mencapai nilai yang luar biasa, hal itu belum bisa dikatakan berhasil sepenuhnya, kaarena keberhasilan tingkat pemahaman keagamaan tidak berhenti hanya sampai pada perolehan nilai akademis saja. Lebih dari itu haruslah mempu mencapai tingkat kebiasaan dimana seorang siswa melakukan ibadah itu sebagai kebutuhan yang tanpa terpaksa ia akan menjalankannya dengan suka rela. Selain itu, dapat dipahami bahwa guru merupakan tokoh sentral dalam pengembangan sumber daya manusia, sebab andai kata didalam sebuah kegiatan pendidikan yang terdiri dari komponen-komponen itu kehilangan beberapa komponennya tersebut, namun jika masih ada sosok seorang guru maka sebuah proses pendidikan masih bisa berjalan. Karena guru merupakan pelaku yang mentransformasikan ilmu kepada peserta didik, bahkan gurulah yang menanamkan nilainilai kepada peserta didik. ${ }^{9}$

Peran pendidik dalam islam adalah sebagai murabbi, mu'allim dan mu'addib sekaligus. Pengertian murabbi mengisyaratkan bahwa guru agama harus orang yang memiliki rabbani yaitu orang yang bijaksana, terpelajar dalam bidang pengetahuan arRabb. Selain itu memiliki sikap tanggung jawab dan penuh kasih sayang. ${ }^{10}$ Murabbi berperan sebagai orang yang menumbuhkan, mengarahkan, membimbing dan mengayomi. pendidik bertindak dengan prinsip, berada di depan siswa dengan memberi contoh, berada di tengah dan memberikan sambil bergaul dan memotivasi, berada di belakang melakukan pengamatan dan supervisi atas berbagai aktivitas belajar. ${ }^{11}$

\section{METODE}

Metode penelitian yang di gunakan dalam penelitian ini adalah metode penelitian kualitatif deskriptif, penelitian kualitatif sebagaimana pendapat Ulin Biki dengan pengutip pendapat Bogdan dan Taylor adalah prosedur penelitian yang menghasilkan data deskriptif berupa kata-kata tertulis atau lisan dari orang-orang dan perilaku yang diamati. Metode kualitatif ini di gunakan oleh peneliti karena data yang telah terkumpul baik memalui observasi, interview, wawancara, dan dokumen-dokumen kemudian

\footnotetext{
${ }^{9}$ Sidik, Firman. "Guru Berkualitas Untuk Sumber Daya Manusia Berkualitas." Tadbir: Jurnal Manajemen Pendidikan Islam 4.2 (2016): 109-114.

${ }^{10}$ chabib Thaha, kapita selekta pendidikan islam, (yogyakarta: pustaka pelajar, 1996) hal. 11

${ }^{11}$ Abuddinata, ilmu pendidikan islam dengan pendekatan multi disipliner: normatif perenialis, sejarah filsafat, psikologi, sosiologi, manajemen, teknologi, informasi, kebudayaan, politik; hukum, (jakarta: PT Rajagrafindo persada,2010) hal. 65.
} 


\section{Irfani}

ISSN 1907-0969 E ISSN 2442-8272

Volume 15 Nomor 2 Desember 2019

Halaman 53-58

http://journal.iaingorontalo.ac.id/index.php/ir

digambarkan dalam bentuk kata-kata dengan terlebih dahulu menganalisis secara tajam terhadap data yang telah terkumpul. Jenis penelitian yang di gunakan adalah penelitian studi kasus, yakni suatu bentuk penelitian yang berusaha memberikan gambaran secara sistematis dan cermat melalui fakta-fakta yang di teliti. Penelitian studi kasus adalah jenis penelitian yang memberikan gambaran atau uraian atas suatu keadaan sejernih tanpa ada perlakuan khusus terhadap objek yang di teliti. ${ }^{12}$

Jenis penelitian kualitatif / non statistik dengan metode deskriptif memiliki penelitian yang terbatas pada usaha mengungkapkan suatu masalah dan keadaan sebagaimana adanya, sehingga hanya merupakan penyikapan fakta, mencari informasi tentang keadaan secara nyata atau suatu gambaran yang jelas dan akurat tentang fenomena yang sedang di teliti.

\section{HASIL PENELITIAN}

Bentuk kenakalan siswa di SMK Negeri 1 Bone Raya sebagai berikut:

a. Melanggar ketentuan seragam sekolah,

b. Tidak masuk sekolah tanpa izin/keterangan

c. Pulang belum waktunya,

d. Tidak mengikuti upacara,

e. Di kantin waktu jam pelajaran,

f. Berambut panjang bagi laki - laki /dicat,

g. Ramai saat pelajaran berlangsung,

h. Merokok,

i. Tidak mengerjakan tugas,

j. Tidak mengikuti pelajaran dan bermain playstation,

k. melakukan tauran antara sekolah,

1. mencuri barang teman.

Peran guru Pendidikan Agama Islam dalam mengatasi masalah kenakalan remaja di SMK Negeri 1 Bone Raya, Bersifat Preventif yaitu: Kegiatan Ramadhan, Istighosah, mentoring/ kajian agama Islam. Bersifat Kuratif yaitu :

1) Langkah penanganan secara umum berupa :

a) Teguran dan nasehat dengan pendekatan keagamaan.

b) Memberikan perhatian khusus secara wajar kepada siswa yang bermasalah.

c) Melakukan kerjasama dengan orang tua siswa yang bermasalah dalam mengatasi kenakalan anaknya.

2) Langkah penanganan secara khusus bagi siswa yang bermasalah dengan jalan melakukan pendekatan kasus perkasus secara individual.

Faktor-faktor penghambat peran guru pendidikan agama islam dalam mengatasi kenakalan remaja di SMKN 1. Bone Raya diantaranya adalah :

${ }^{12}$ Kountur Ronny, Metode Penelitian Untuk Penulisan Skripsi Dan Tesis,(Jakarta: PPM, 2004), h. 


\section{Irfani}

ISSN 1907-0969 E ISSN 2442-8272

Volume 15 Nomor 2 Desember 2019

Halaman 53-58

http://journal.iaingorontalo.ac.id/index.php/ir

1) masih kurangnya kesadaran dari orang tua terhadap pendidkan anak.

2) kurangnya pengawasan orang tua terhadap kehidupan pergaulan anak.

3) Adanya Broken home

4) kurangnya kesadaran dari diri siswa untuk mematuhi tata tertib sekolah.

5) Semakin banyak program televisi yang tidak mendidik.

\section{DAFTAR PUSTAKA}

Abuddinata. 2010. ilmu pendidikan islam dengan pendekatan multi disipliner: normatif perenialis, sejarah filsafat, psikologi, sosiologi, manajemen, teknologi, informasi, kebudayaan, politik; hukum. Jakarta: PT Rajagrafindo persada.

Darajat, Zakiyah, dkk. 1996. Ilmu Pendidikan Islam. Bumi Aksara, Jakarta.

Maunah, Binti. 2009. landasan pendidikan. Yogyakarta : Teras

Muhaimin. 2012. paradigma pendidikan islam upaya mengefektifkan pendidikan islam di sekoalah. Bandung: PT remaja rosdakarya.

Mujib, Abdul, et al. ilmu pendidikan islam. Jakarta: Prenada Media

Ronny, Kountur. Metode Penelitian Untuk Penulisan Skripsi Dan Tesis. Jakarta: PPM. 2004.

Sidik, Firman. "KONSEP PENGEMBANGAN KURIKULUM PENDIDIKAN ISLAM." (2016): 100-114.

Sidik, Firman. "Guru Berkualitas Untuk Sumber Daya Manusia Berkualitas." Tadbir: Jurnal Manajemen Pendidikan Islam 4.2 (2016): 109-114.

Suparlan. 2008.wawasan pendidikan. Yogyakarta: Ar-Ruzz Media. 